\title{
The Effectiveness of Science Learning using Contextual Teaching and Learning to Improve Elementary School Students' Critical Thinking Skills
}

\author{
Z. Zaifaro, Muhari, B. Jatmiko \\ Universitas Negeri Surabaya \\ Departement of primary education \\ Surabaya, Indonesia \\ zaimatuszaifaro@gmail.com
}

\begin{abstract}
This study aims to examine the effectiveness of science learning which applied Contextual Teaching and Learning (CTL) to improve the critical thinking skills of elementary school students on the topic of balance and preservation of natural resources. This research is a part of a development study with the main focus on the analysis of the effectiveness of learning aids using one group pre-test post-test. The study was conducted at SD Al Muslim, one of the primary schools (SD) in East Java, with a total sample of 80 students divided into three classes. Before the learning with CTL approach was carried out, students were given pre-test of Critical Thinking Skills (KPS) and after learning, students were again given the same KPS test as the final test (post-test). Data in the form of KPS skills, activities, and student responses were respectively collected using KPS test instrument, student activity observation sheet, and student response question. The collected data were then analyzed using a paired t-test, ANOVA, and descriptive analysis. Research has shown that CTL-based science learning is effective in improving students' critical thinking skills.
\end{abstract}

\section{Keywords-Critical Thinking Skills, Natural Sciences}

\section{INTRODUCTION}

Critical thinking skill is an important aspect to be developed in the students' learning process (Jawa Pos, 2017: 11). This is because the mastery of students' concepts of certain learning material can be improved through the development of students' critical thinking (Stiawan, 2014: 258). There are several reasons why critical thinking skills are important to be studied and developed in the learning process. First, the fast growth of information and global competition today requires the ability of high-level thinking in solving complex problems, which is often unpredictable (Saavedra \& Opfer, 2012: 8). In this regard, critical thinking skills play important roles in the era of global competition since the level of complexity of problems in all aspects of modern life becomes higher (Facione, 2006). Also, critical thinking is known as an essential aspect in analyzing, synthesizing, and evaluating all arguments in order to be able to make rational and responsible decisions. Furthermore, one of the skills as key to survival in a changing world is critical thinking skills; thus the basis of the education system should be adjusted (Fischer, 2003). Besides, the benefits the students will have is the ability to solve problems both in the process of teaching and learning in the classroom or in the face of real problem experienced (Stiawan, 2014: 258). Research also show that many students have low critical thinking skills (Nisa, 2017). The results of interviews with school teachers around SD Al Muslim, an elementary school at Surabaya city, indicate that there are schools that do not have CTL-based natural science learning tools that can train and develop their critical thinking skills. This is also to solve a problem encountered in everyday life, through scientific activities or investigation, especially on the topic of the development and conservation of natural resources.

Nickerson (1987) stated, "with or without special training, everyone thinks". However, Nickerson (1994) suggested that what people should learn is "how to think more effectivelymore critically, more coherently, more creatively, more deeply than we often, perhaps typically do". Perhaps it is the ability to think and connect ideas that are the mark of a gifted person. If this is the case, then critical-thinking activities for gifted students are not options, but, rather, essential elements of every lesson conducted every day. If gifted students think critically on a regular basis, activities that do not give them a chance to exercise this strength are simply a waste of time. This study aims to find out how the effectiveness of natural science learning based on Contextual Teaching and Learning (CTL) in improving the critical thinking skills of elementary school students in science learning balance and preservation of natural resources. The result of a preliminary study of students' critical thinking skills test conducted at SD Al Muslim in a sample of fourth-grade students on balance and preservation of natural resources shows that only $20 \%$ of students are able to think critically. This means that the students' critical thinking skills in understanding the topic of balance and conservation of natural resources are still categorized as low-level understanding. Before the natural science learning with CTL approach was carried out, students were given pre-test of Critical Thinking Skills (KPS) and after learning, students were again given the same KPS test as the final test (post-test). Data in the form of KPS skills, activities, and student responses were collected using KPS test instrument, student activity observation sheet, and student response question. The collected data were then analyzed using a paired t-test, ANOVA, and descriptive analysis. One-Way ANOVA for N-gain test results 
of increasing critical thinking skills for the three classes obtained sig score $=0,119>0.05$, which means that the average increase of $\mathrm{N}$-gain for the three classes is identical. Thus it can be concluded that the increase in $\mathrm{N}$-gain for the three classes is consistent (see Table 7).

\section{METHOD}

This study used one group pre-test post-test design. In this study, the data collected directly by researchers by giving treatment to the class of experiments, observations, and questionnaires. Before the implementation of CTL-based learning, a preliminary test (pre-test) was performed, and after CTL-based learning was done, a final test (post-test) was performed.

The effectiveness of CTL-based learning is said to be effective if students critical thinking skills test increased significantly with the result of paired t-test sig $<0.05$, the percentage of student activity was in the range of $80 \%-100 \%$ and the percentage of students' responses was in the range $\geq$ $85 \%$. The paired t-test was performed using significance level $\alpha=0.05$ (2-tailed). The score of pre-test obtained was tested for normality through the statistical test by using Shapiro-Wilk test with significance level $\alpha=0.05$ (2-tailed). The results of pre-test and post-test of students critical thinking skills were then analyzed with $\mathrm{N}$-gain. The use of this technique is used to determine the level of KPS level increase of each student shown by the score (N-gain).

N $\quad$ - gain $=$ Spost $\square$ Spre Smax $\square$ Spre

(Hake, 1999)

where $\mathrm{N}$-gain = gainscore;

Spost $=$ post-test score;

Spre $=$ pre-test score.

One-Way ANOVA statistical test was conducted in order to know the consistency of the average level of improvement of students' critical thinking skill, N-gain average after given CTL based learning in all three classes. The critical thinking skills test developed consisted of 11 descriptive questions in accordance with the indicator of critical thinking skills to be achieved. Learning tools in the form of a syllabus, lesson plan, BAS, worksheet, and KPS test used in this study have been validated with the following results.

TABLE I. LEARNING TOOL VALIDATION RESULT

\begin{tabular}{|c|c|c|}
\hline Tool & Average & Compatibility Level \\
\hline Syllabus & 4.00 & $100 \%$ \\
\hline Lesson plan & 3.93 & $98.25 \%$ \\
\hline BAS & 4.00 & $100 \%$ \\
\hline Worksheet & 3.88 & $97.21 \%$ \\
\hline KPS test & 3.92 & $96.25 \%$ \\
\hline
\end{tabular}

Table. 1 shows the average assessment of the syllabus of the validator is 4.00 with a compatibility level of $100 \%$, lesson plan 3.93 with a compatibility level of $98.25 \%$, BAS 4.00 $100 \%$ compatibility level, worksheet 3.88 of $97.21 \%$ compatibility level, KPS test 3.92 of 96.25 compatibility level. Because it is in the range $3.6 \leq \mathrm{x} \leq 4.0$ then it is very valid or can be used without revision (Nisa, 2017: 60).

\section{RESUlTS AND DisCUSSION}

Preliminary test result (pre-test) of critical thinking achieved mean of 25.9 and after CTL based learning there is an increase in the average value reaching 89,59 . The paired t-test results show the overall sig value $<0.05$ and the value $t$ of the calculated value are negative. This means that there is a significant increase between the pre-test and post-test scores of students' critical thinking skills; (see Table 2). The extent of the student's level of KPS improvement in the topic of balance and the preservation of natural resources by using CTL-based learning is obtained by $\mathrm{N}$-gain calculation from pre-test and post-test. Tables 3 and 4 show pre-test and post-test data coming from normally distributed populations. Based on Table 5 it can be seen that the average increase of KPS class IV students of Ibnu Sina 0.84, class students of Ibnu Rusydi 0.86, and class students of Ibn Khaldun 0.88; This means that students in all three classes are experiencing the critical thinking skills increased with high levels.

Based on Table 6. the homogeneity test of the average increase of $\mathrm{N}$-gain for the three classes obtained the sig value $=$ 0.177 ; this means the three classes have the same variance. Thus, it can be concluded that the increase in the average $\mathrm{N}$ gain of the three classes comes from a population that is normally distributed and homogeneous. Result of One-Way ANOVA $\mathrm{N}$-gain test results of increasing critical thinking skills for the three classes indicates that the sig score is $0.119>$ 0.05 . This means that the average increase of $\mathrm{N}$-gain for the three classes is identical. Thus, it can be concluded that the increase in $\mathrm{N}$-gain for the three classes is consistent (see Table 7).

TABLE II. T-TEST PAIRED WITH CRITICAL THINKING SKILLS TEST RESULT LET

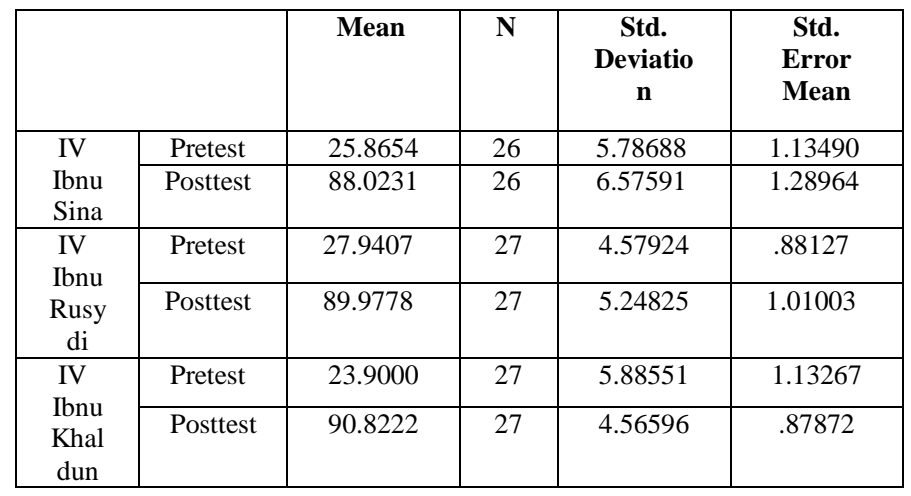

TABLE III.

NORMALITY PRE-TEST TEST RESULT

\begin{tabular}{|c|c|c|c|c|c|c|}
\hline \multirow{2}{*}{} & \multicolumn{2}{|c|}{ Kolmogorov-Smirnov } & \multicolumn{3}{c|}{ Shapiro-Wilk } \\
\cline { 2 - 7 } & $\begin{array}{c}\text { Statis } \\
\text { tics }\end{array}$ & Df & Sig. & $\begin{array}{c}\text { Statis } \\
\text { tics }\end{array}$ & df & Sig. \\
\hline $\begin{array}{c}\text { Pre_Test_K_I } \\
\text { V_Ibnu_Sina }\end{array}$ & .136 & 26 & .200 & .935 & 26 & .103 \\
\hline $\begin{array}{c}\text { Pre_Test_K_I } \\
\text { V_Ibnu_Rusy } \\
\text { di }\end{array}$ & .115 & 27 & .200 & .971 & 27 & .626 \\
\hline $\begin{array}{c}\text { Pre_Test_K_I } \\
\text { V_Ibnu_Khald } \\
\text { un }\end{array}$ & .163 & 27 & .065 & .928 & 27 & .063 \\
\hline
\end{tabular}


TABLE IV. NORMALITY POST-TEST TEST RESULT

\begin{tabular}{|c|c|c|c|c|c|c|}
\hline & \multicolumn{2}{|c|}{ Kolmogorov-Smirnov } & \multicolumn{3}{c|}{ Shapiro-Wilk } \\
\cline { 2 - 7 } & $\begin{array}{c}\text { Statis } \\
\text { tics }\end{array}$ & Df & Sig. & $\begin{array}{c}\text { Statis } \\
\text { tics }\end{array}$ & df & Sig. \\
\hline $\begin{array}{c}\text { Pre_Test_K_I } \\
\text { V_Ibnu_Sina }\end{array}$ & .136 & 26 & .200 & .935 & 26 & .103 \\
\hline $\begin{array}{c}\text { Pre_Test_K_I } \\
\text { V_Ibnu_Rusy } \\
\text { di }\end{array}$ & .115 & 27 & .200 & .971 & 27 & .626 \\
\hline $\begin{array}{c}\text { Pre_Test_K_I } \\
\text { V_Ibnu_Khal } \\
\text { dun }\end{array}$ & .163 & 27 & .065 & .928 & 27 & .063 \\
\hline
\end{tabular}

TABLE V.

N-AGAIN AVRAGE

\begin{tabular}{|c|c|}
\hline Kelas & Mean N-gain \\
\hline IV Ibnu Sina & 0.84 \\
\hline IV Ibnu Rusydi & 0.86 \\
\hline IV Ibnu Khaldun & 0.88 \\
\hline
\end{tabular}

TABLE VI. NTEST OF HOMOGENEITY OF VARIANCES

\begin{tabular}{|c|c|c|c|}
\hline Levene Statistic & df1 & df2 & Sig. \\
\hline 1.773 & 2 & 77 & .177 \\
\hline
\end{tabular}

TABLE VII. ONE WAY ANOVA RESULT

\begin{tabular}{|c|c|c|c|c|c|}
\hline \multicolumn{7}{|c|}{ N-Gain } \\
\hline & $\begin{array}{c}\text { Sum of } \\
\text { Squares }\end{array}$ & df & $\begin{array}{c}\text { Mean } \\
\text { Square }\end{array}$ & F & Sig. \\
\hline $\begin{array}{c}\text { Between } \\
\text { Groups }\end{array}$ & .022 & 2 & .011 & 2.186 & .119 \\
\hline $\begin{array}{c}\text { Within } \\
\text { Groups }\end{array}$ & .388 & 77 & .005 & & \\
\hline Total & .411 & 79 & & & \\
\hline
\end{tabular}

Observations from both observers indicate that student activity during learning is very good. The average of observation result from both observers showed that the students' activity of class IV Ibnu Sina is 3.90 with the percentage of implementation is $97.5 \%$, class IV students of Ibnu Rusydi is 3.88 with the percentage of implementation is $97 \%$, and class IV students of Ibnu Khaldun 3.86 with the percentage of implementation is $96.5 \%$. The result of student activity average score is in the interval of $80 \%-100 \%$, which means student activity during CTL-based natural science learning is excellent (see Table 8). The responses given by the students are in very positive category (see Figure 1). Data of Figure 1 shows the responses of 80 students. The responses include 1) students are interested in learning materials, worksheet, BAS, KBM stages, questions are given; 2) students think that the learning is new in formulating problems and hypotheses, conducting investigation/practicum activities, analyzing investigation data; 3 ) students were glad when doing activities to formulate problems and hypotheses, conducting investigations/lab work, making conclusions, analysing problems; 4) easy to formulate problems on phenomena, formulate problems, conduct investigation/lab work, make conclusions, analyze daily problems; 5) eager to do the learning activities as done in this lesson on other topics.
TABLE VIII. STUDENT ACTIVITY AVERAGE

\begin{tabular}{||c|c|}
\hline Class & Activity Average \\
\hline IV Ibnu Sina & 3.90 \\
\hline IV Ibnu Rusydi & 3.88 \\
\hline IV Ibnu Khaldun & 3.86 \\
\hline
\end{tabular}

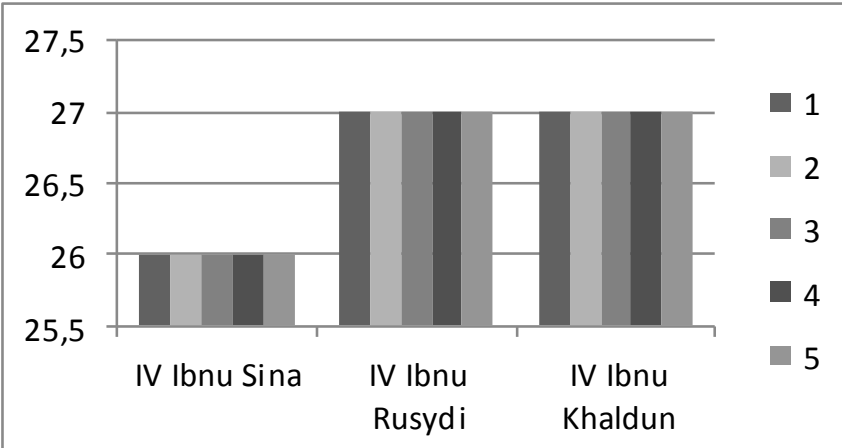

Figure 1. Student's Response to Teaching and Learning Activities

Overall, the average of the increase of critical thinking for those three classes is in high category. This is due to during the learning process, students are trained to be able to make a problem of analysis based on the illustration in the worksheet and phenomena that occur in daily life. Based on research data and communicated with variable operational definition, CTLbased learning is said to be effective because it successfully improves critical thinking skills (see Table 5). The results support and confirm the correctness of constructivist theory (Slavin, 2009) that students must find themselves and transform complex information, check new information with old rules and revise if the rules are no longer appropriate. This means students build their own knowledge in their minds meaningfully with student-centered teaching. The results showed that to gain knowledge or information students must actively build their own knowledge through learning activities. The data is also supported by previous researchers that the application of learning-based CTL can complete and improve the learning outcomes of biology students at faculty of mathematics and science, The state university of surabaya on Aves class.

CTL-based learning provides opportunity and helps the students to gain an understanding of scientific methods in order to develop critical thinking skills, self-regulation, and understanding of specific topics (Eggen, 2012). This is reinforced by Glacier's opinion (in Fisher, 2003), which states that critical thinking is a knowledge of inquiry or discovery. In addition, Tyler (in Redhana, 2003: 21) says that learning that provides opportunities for students to acquire skills in problemsolving will improve critical thinking skills. In addition, Tyler (in Redhana, 2003) argues that learning that provides opportunities for students to acquire skills in problem-solving will improve critical thinking skills. According to the research of L.M. Sartorelli and R. Swartz (in Hassoubah, 2004:96-110), there are several ways to improve critical thinking skills including improving analytical skill and developing 
observational skill. According to Facione (2016), someone with critical thinking skill must be proficient in a certain cognitive skill, such as; skillful in doing interpreting, analyzing, evaluating, resuming, explaining, self-regulation, and developing character (disposition) to the critical thinking. The higher the level of critical thinking, the higher the level of difficulty. Furthermore, according to Langrehr (2006), to train the critical thinking, students should be encouraged to answer questions that related to the following: (1) determine the consequence of a decision or event; (2) identify the assumption that used in a sentence. (3) determine the main issues. (4) find a bias based on the various point of view. (5) uncover the cause of an event. (6) choose some factors that support a decision.

\section{CONCLUSION}

Contextual Teaching and Learning (CTL) of natural science learning is very effective in improving students' critical thinking skills shown by the finding that there is a significant increase in alpha $5 \%$ and the $\mathrm{N}$-gain is categorized as high category. Suggestions that can be submitted by researchers: teachers/other researchers can make this research as a reference in learning natural science-based on Contextual Teaching and Learning (CTL) on other topics and other levels.

\section{REFERENCES}

[1] Eko Priyono. 2008. Pemanfaatan Kebun Binatang Surabaya (KBS) Sebagai Media Perkuliahan Berorientasi Contextu-al Teaching and Learning (CTL) Mata Kuliah Taksonomi Hewan II. (Tesis master tidak dipublikasikan). Universitas Negeri Surabaya, Indonesia.

[2] Facione, P. 2006. Critical Thinking: What It Is and Why Its Counts. Insight Assesment. Millbrae CA: California Academic Press.

[3] Fisher, A. 2003. Critical Thinking An Introduction. New Yor: Cambridge University Press.

[4] Forawi, S.A. 2016. Standard-Based Science Education and Critical Thinking. ScienceDirect. 20, 52-62.

[5] Hake, R.R. 1999. American Educational Research Association's Division, Measurement Research Methodology Analyzing Change/Gain Scores. USA: Woodland Hills.

[6] Hargenhahn, B.R. \& Olson, M.H. 2008. Theories of Learning (Teori Belajar) Edsi Bahasa Indonesia. Jakarta: Kencana Prenada Media Group.
[7] Hassoubah, Z. I. 2004. Mengasah Pikiran Kreatif dan Kritis. Jakarta: Nuansa.

[8] Heong, Y. M., Othman, W.D., Md Yunos, J., Kiong T.T., Hassan, R., \&Mohammad, M.M. 2011. The Level of Marzano Higher Order Thinking Skill Among Technical Education Students. International Journal of Social and Humanity, volume. 1(2), 121-125.

[9] Jawa Pos. 2017. Hadapi Siswa Kritis Pendidik Harus Beru-bah. Surabaya: Harian Jawa Pos p.11.

[10] Langrehr, J. 2006. Thinking Skills Edisi Pertama. Jakarta: Gramedia.

[11] Milner, A.R., Templin, M.A. \& Czerniak, C.M. 2011. Elementary Science Students' Motivation and Learning Strategy Use: Constructivist Classroom Contextual Factors in a Life Science Laboratory and a Traditional Classroom. J Sci Teacher Education 22:151-170.

[12] Nickerson, R. S. 1987. Why teach thinking? In J. B. Baron \& R. J. Sternberg [Eds.], Teaching thinking skills: Theory and Practice. New York: Freeman.

[13] Nickerson, R. S. 1994. The teaching of thinking and problem-solving. In R. J. Sternberg (Ed.), Thinking and problem-solving. San Diego, CA: Academic Press.

[14] Nirahua, J. 2012. Pembelajaran Pembelajaran Fisika SMA materi Kalor dengan Pendekatan ontekstual (CTL). (Tesis master tidak dipublikasikan). Universitas Negeri Surabaya, Indonesia.

[15] Nisa, E. 2017. Pengembangan Perangkat Pembelajaran Fluida Statis dengan Model Inkuiri Terbimbing untuk Meningkatan Keterampilan Berpikir Kritis Siswa SMA. (Tesis master tidak dipublikasikan). Universitas Negeri Surabaya, Indonesia.

[16] Redhana, I. W.2003. Menngkatkan Keterampilan Berpikir Kritis Siswa Melalui Pembelajaran Kooperatif dengan Strategi Pemecahan Masalah. Jurnal Penddikan dan Pengajaran XXXVII. II: 11-21.

[17] Saavedra, A.R., dan Opfer, D.V. 2012. Learning 21st-Century Skills Requires 21st-Century Teaching. Kappan Magazine. V94N2. p.8-12.

[18] Slavin, Robert. E. 2009. Cooperative Learning (Teori, Riset, Praktik). Bandung: Nusa Media.

[19] Stiawan, E. 2014. Pengembangan Keterampilan Berpikir Kritis Siswa SMA pada Topik Teori Domain Elektron melalui Simulasi Interaktif PhET Molecule Shapes. Jurnal Pengajaran MIPA, volume 19, Nomor 2, 257-265.

[20] Syahbana, Ali. 2012). Peningkatan Kemampuan Berpikir Kritis Matematis Siswa SMP Melalui Pendekatan Contextual Teaching and Learning. Edumatica, volume 02, Nomor 01.

[21] Thiagaradjan, S. 1974. Instructional Development for Training Teachers of Exceptional Children. Minnesota: Indiana University.

[22] Tri, Indrayani. 2013. Pengembangan Perangat Pembelaja-ran Biologi dengan Pendekatan CTL untuk Mengajarkan Life Skill Siswa SMA. (Tesis master tidak dipublikasikan). Universitas Negeri Surabaya, Indonesia.. 